\title{
Synthesis of racemic and chiral BEDT-TTF derivatives possessing hydroxy groups and their achiral and chiral charge transfer complexes
}

\author{
Sara J. Krivickas ${ }^{1,2}$, Chiho Hashimoto ${ }^{1}$, Junya Yoshida ${ }^{1}$, Akira Ueda ${ }^{1}$, \\ Kazuyuki Takahashi ${ }^{1,3}$, John D. Wallis ${ }^{4}$ and Hatsumi Mori ${ }^{* 1}$
}

\section{Full Research Paper}

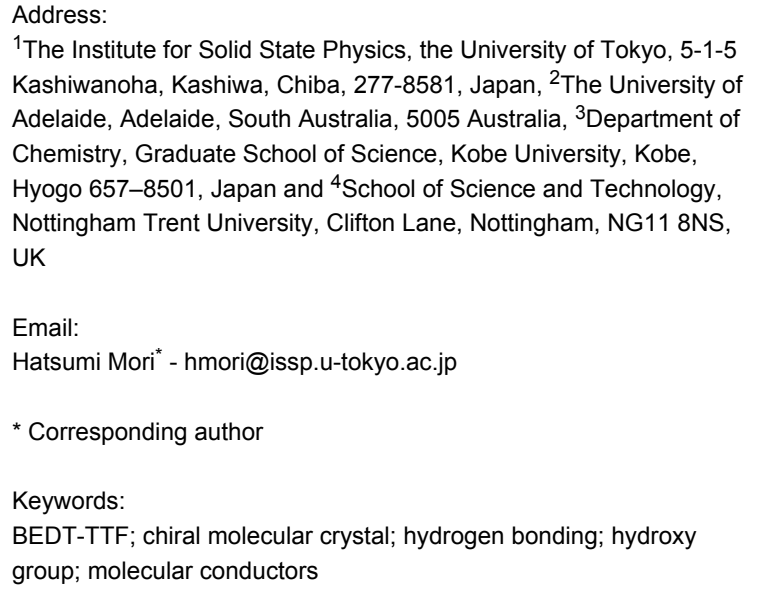

${ }^{1}$ The Institute for Solid State Physics, the University of Tokyo, 5-1-5 Kashiwanoha, Kashiwa, Chiba, 277-8581, Japan, ${ }^{2}$ The University of Adelaide, Adelaide, South Australia, 5005 Australia, ${ }^{3}$ Department of Chemistry, Graduate School of Science, Kobe University, Kobe, Hyogo 657-8501, Japan and ${ }^{4}$ School of Science and Technology, Nottingham Trent University, Clifton Lane, Nottingham, NG11 8NS, UK

Email:

Hatsumi Mori* - hmori@issp.u-tokyo.ac.jp

${ }^{*}$ Corresponding author

Keywords:

BEDT-TTF; chiral molecular crystal; hydrogen bonding; hydroxy

group; molecular conductors

Beilstein J. Org. Chem. 2015, 11, 1561-1569. doi:10.3762/bjoc.11.172

Received: 08 June 2015

Accepted: 21 August 2015

Published: 08 September 2015

This article is part of the Thematic Series "Tetrathiafulvalene chemistry".

Guest Editor: P. J. Skabara

(c) 2015 Krivickas et al; licensee Beilstein-Institut.

License and terms: see end of document.

\begin{abstract}
Chiral molecular crystals built up by chiral molecules without inversion centers have attracted much interest owing to their versatile functionalities related to optical, magnetic, and electrical properties. However, there is a difficulty in chiral crystal growth due to the lack of symmetry. Therefore, we made the molecular design to introduce intermolecular hydrogen bonds in chiral crystals. Racemic and enantiopure bis(ethylenedithio)tetrathiafulvalene (BEDT-TTF) derivatives possessing hydroxymethyl groups as the source of hydrogen bonds were designed. The novel racemic trans-vic-(hydroxymethyl)(methyl)-BEDT-TTF 1, and racemic and enantiopure trans-vic-bis(hydroxymethyl)-BEDT-TTF 2 were synthesized. Moreover, the preparations, crystal structure analyses, and electrical resistivity measurements of the novel achiral charge transfer salt $\theta^{21}-[(S, S)-2]_{3}[(R, R)-2]_{3}\left(\mathrm{ClO}_{4}\right)_{2}$ and the chiral salt $\alpha^{\prime}-[(R, R)-2] \mathrm{ClO}_{4}\left(\mathrm{H}_{2} \mathrm{O}\right)$ were carried out. In the former $\theta^{21}-[(S, S)-2]_{3}[(R, R)-2]_{3}\left(\mathrm{ClO}_{4}\right)_{2}$, there are two sets of three crystallographically independent donor molecules $[(S, S)-\mathbf{2}]_{2}[(R, R)-2]$ in a unit cell, where the two sets are related by an inversion center. The latter $\alpha^{\prime}-[(R, R)-2] \mathrm{ClO}_{4}\left(\mathrm{H}_{2} \mathrm{O}\right)$ is the chiral salt with included solvent $\mathrm{H}_{2} \mathrm{O}$, which is not isostructural with the reported chiral salt $\alpha^{\prime}-[(S, S)-$ 2] $\mathrm{ClO}_{4}$ without $\mathrm{H}_{2} \mathrm{O}$, but has a similar donor arrangement. According to the molecular design by introduction of hydroxy groups and $\mathrm{a} \mathrm{ClO}_{4}{ }^{-}$anion, many intermediate-strength intermolecular hydrogen bonds (2.6-3.0 $\AA$ ) were observed in these crystals between electron donor molecules, anions, and included $\mathrm{H}_{2} \mathrm{O}$ solvent, which improve the crystallinity and facilitate the extraction of physical properties. Both salts are semiconductors with relatively low resistivities at room temperature and activation energies of $1.2 \mathrm{ohm} \mathrm{cm}$ with $E_{\mathrm{a}}=86 \mathrm{meV}$ for $\theta^{21}-[(S, S)-2]_{3}[(R, R)-2]_{3}\left(\mathrm{ClO}_{4}\right)_{2}$ and $0.6 \mathrm{ohm} \mathrm{cm}$ with $E_{\mathrm{a}}=140 \mathrm{meV}$ for $\alpha^{\prime}-[(R, R)-2]_{2} \mathrm{ClO}_{4}\left(\mathrm{H}_{2} \mathrm{O}\right)$,
\end{abstract}


respectively. The variety of donor arrangements, $\theta^{21}$ and two kinds of $\alpha^{\prime}$-types, and their electrical conductivities of charge transfer complexes based upon the racemic and enantiopure $(S, S)-\mathbf{2}$, and $(R, R)-\mathbf{2}$ donors originates not only from the chirality, but also the introduced intermolecular hydrogen bonds involving the hydroxymethyl groups, perchlorate anion, and the included solvent $\mathrm{H}_{2} \mathrm{O}$.

\section{Introduction}

The chiral crystals without an inversion center have attracted much interest recently. Non-centrosymmetric crystals can exhibit a variety of physical properties related to their crystal class [1]; optical and magneto-optical phenomena such as secondharmonic generation, Faraday and Kerr effects, magneto-chiral dichroism, and electrical and magneto-electrical phenomena such as piezoelectricity, pyroelectricity, ferroelectricity and electrical magnetochiral anisotropy. Rikken et al. observed magneto-chiral dichroism in a europium complex $[2,3]$ and also electrical magneto-chiral anisotropy in carbon nanotubes where small changes in the resistance of the chiral carbon nanotubes in a magnetic field were observed between enantiomers [4-6].

One method of constructing chiral crystals is through the use of chiral molecules as building blocks. Tetrathiafulvalene derivatives such as TTF (3) and BEDT-TTF (4) have been investigated considerably due to their ability to form radical cation salts with interesting conductive and magnetic properties (Figure 1). The influence of chirality in the TTF molecules on the crystal structure and physical properties has been shown by Avarvari's $(R)$-, $(S)$ - and racemic $( \pm)$-(ethylenedithio(tetrathiafulvalene)methyloxazoline $)_{2} \mathrm{X},\left(\mathbf{5}_{2} \mathrm{X}, \mathrm{X}=\mathrm{AsF}_{6}\right.$ [7], $\mathrm{PF}_{6}$ [8]) where disorder within the racemic salt leads to lower conductivity. Recently, Pop et al., have also reported electrical magnetochiral anisotropy in chiral molecular conductors, $(R, R)$ - and
$(S, S)$-[dimethyl-(ethylenedithio)tetrathiafulvalene ${ }_{2} \mathrm{ClO}_{4}$ $\left(6_{2} \mathrm{ClO}_{4}\right)[9,10]$.

Although there is a relatively large number of chiral TTF derivatives, only a few conducting properties for chiral cation salts have been so far reported, for those based upon tetramethyl-4 [11-15], 5 [7,8], 6 [9,10], and X-dimethyl-(ethylenedithio)tetrathiafulvalene ( $\mathrm{X}=$ ethylenedithio [16,17], ethylenedioxy [18], and pyrazino [19]), due to the difficulty of chiral-crystal growth. In order to improve the crystallinity, the inclusion of hydroxy groups in the BEDT-TTF molecule has been postulated to produce hydrogen bonding interactions between electron-donor molecules, electron-acceptor molecules, and anions in the subsequent radical cation salts [20-22]. This may lead to improved order in the crystalline state, which in turn may help the observation of physical properties of the salts. Previously, the synthesis of racemic-2 [21,22], the preliminary synthesis of enantiopure $(R, R)$ - and $(S, S)$-2, and the preparation, and crystal structure of the radical cation salt $\alpha^{\prime}-[(S, S)-2]_{2} \mathrm{ClO}_{4}$ [22] have been reported. In this article, we report the syntheses of novel racemic-1 and enantiopure $(R, R)$ - and $(S, S)-\mathbf{2}$ possessing one or two hydroxymethyl groups, and the preparations, crystal structures, and electrical resistivities of the achiral charge transfer complex $\theta^{21}-[(S, S)-2]_{3}[(R, R)-2]_{3}\left(\mathrm{ClO}_{4}\right)_{2}$ and the chiral complex $\alpha^{\prime}-[(R, R)-2]_{2} \mathrm{ClO}_{4}\left(\mathrm{H}_{2} \mathrm{O}\right)$, in comparison with<smiles>C[C@H]1SC2=C(SC(=C3SC4=C(SCCS4)S3)S2)SC1=C1SC2=C(SC(=C3SC4=C(SCCS4)S3)S2)S1</smiles>

$(S, S)-2$<smiles>OCC1SC2=C(SC(=C3SC4=C(SCCS4)S3)S2)SC1CO</smiles>

$(R, R)-2$<smiles>C1=CSC(=C2SC=CS2)S1</smiles>

3<smiles>C1CSC2=C(S1)SC(=C1SC3=C(SCCS3)S1)S2</smiles>

4<smiles>CC1COC(C2=CSC(=C3SC4=C(SCCS4)S3)S2)=N1</smiles>

5<smiles>CC1SC2=C(SC(=C3SC=CS3)S2)SC1C</smiles>

$(S, S)-6$<smiles>CC1SC2=C(SC(=C3SC=CS3)S2)SC1C</smiles>

$(R, R)-6$

Figure 1: Molecular structures of trans-vic-(hydroxymethyl)(methyl)-BEDT-TTF (1), trans-vic-bis(hydroxymethyl)-BEDT-TTF (2), TTF (3), BEDT-TTF (4), EDT-TTF-methyl-oxazoline 5, and trans-dimethyl-EDT-TTF (6). 
those of $\alpha^{\prime}-[(S, S)-2]_{2} \mathrm{ClO}_{4}$. The effects of introducing hydrogen bonds between hydroxymethyl groups of donors and $\mathrm{ClO}_{4}{ }^{-}$ anions in charge transfer complexes are also discussed.

\section{Results and Discussion}

\section{Syntheses of racemic-1, enantiopure $(S, S)$ -} and $(R, R)-2$ and evaluation of their electrochemical properties

The synthesis of the racemic trans-vic-(hydroxymethyl)(methyl)-BEDT-TTF (1) was performed in a similar manner to racemic 2 [22]. The trans-alkene 8 was reacted with trithione 7 under standard Diels-Alder cycloaddition conditions in refluxing toluene to afford a mixture of the trans- $(S, S)$ - and $(R, R)-9$ in $56 \%$ yield (Scheme 1). The purchased alkene contained a small amount of the cis-isomer (trans-form:cisform 96:4), but the cis-product can be removed by simple recrystallization of the thione $\mathbf{9}$ from hexane/dichloromethane.
The racemic donor $\mathbf{1}$ could then be synthesized following procedures whereby the alcohol functionality is protected as acetate, 10, the thione $\mathbf{1 0}$ is then converted to the oxo-analogue 11 using mercuric acetate and acetic acid in chloroform. Oxo compound 11 was then cross-coupled with 1.2 equivalents of thione 12 in triethyl phosphite to afford the racemic protected donor 13 in reasonable yield (37\%). Basic hydrolysis of the acetyl protecting group afforded the racemic donor $\mathbf{1}$ in an $81 \%$ yield. The syntheses of enatiopure donors 1 and the preparations of their charge transfer complexes are under way.

Moreover, enantiopure $(S, S)-\mathbf{2}$ and $(R, R)-\mathbf{2}$ were also synthesized as shown in Scheme 2. Chiral HPLC was performed using a JAIGEL-OA7500 column on a JAI LC-908 recycling preparative system using the solvent system methanol/water 7:3 to separate $(S, S)$ - and $(R, R)-\mathbf{1 4}$. The obtained dihydroxy-thione $(S, S)-\mathbf{1 4}$ was protected as a diacetate to give $(S, S) \mathbf{- 1 5}$, which was converted to the oxo-form $(S, S)$-16, and coupled with

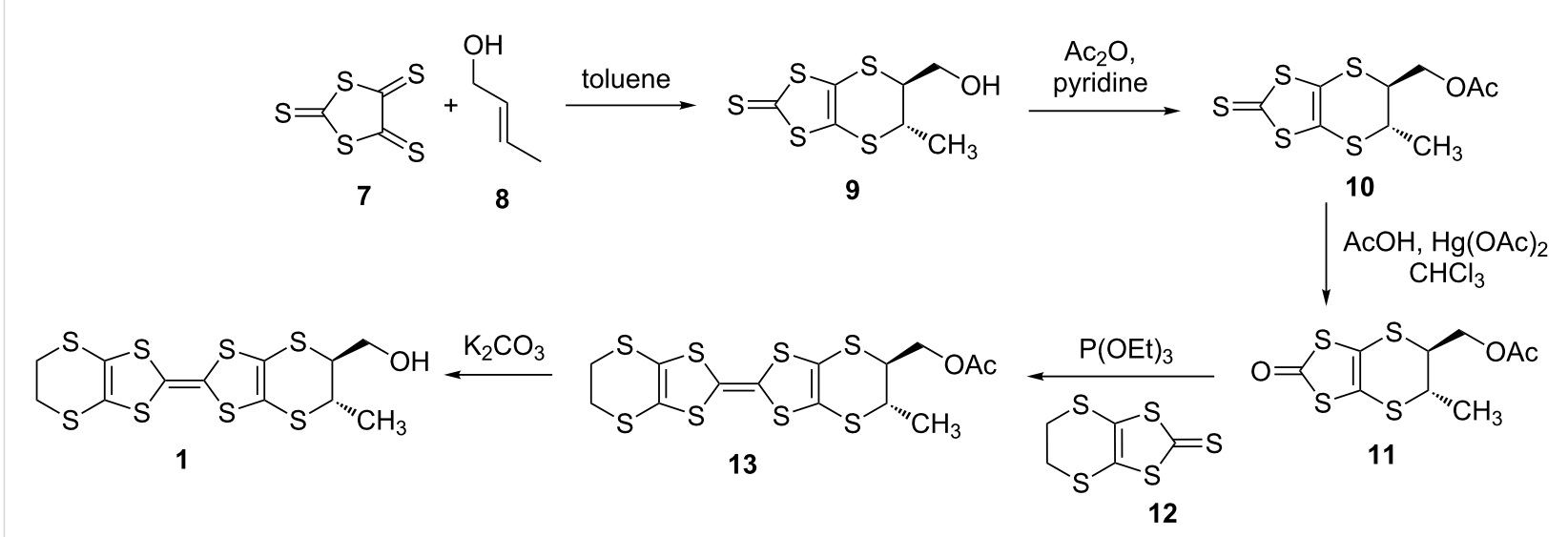

Scheme 1: Synthesis of donor trans-1.<smiles>OCC1Sc2sc(=S)sc2Sc2sc(=S)sc2S1</smiles>

$(S, S)$ and $(R, R)-14$

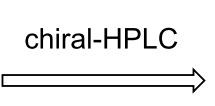<smiles>OC[C@@H]1Sc2sc(=S)sc2S[C@@H]1CO</smiles>

one enantiomer

$(S, S)-14$<smiles>CC(=O)OC[C@@H]1Sc2sc(=S)sc2S[C@@H]1COC(C)=O</smiles>

$(S, S)-15$

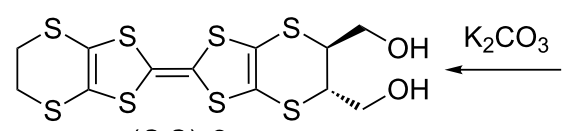

$(S, S)-2$<smiles>CC(=O)OC[C@H]1SC2=C(SC(=C3SC4=C(SCCS4)S3)S2)S[C@@H]1COC(C)=O</smiles>

$(S, S)-17$<smiles>CCOCCOC</smiles>

12, 2 equiv<smiles>CC(=O)OCC1Sc2sc(=O)sc2SC1COC(C)=O</smiles>

$(S, S)-16$ 
2 equivalents of $\mathbf{1 2}$ to give $(S, S)$-17. Deprotection under basic conditions afforded enantiopure $(S, S)-\mathbf{2}$. The other enantiomer $(R, R)-2$ was synthesized in the same manner.

The cyclic voltammetry measurement on racemic-1 indicated the first and second oxidation potentials $\left(E_{1 / 2}^{1}, E^{2}{ }_{1 / 2}\right)$ and their difference $\Delta E\left(=E_{1 / 2}^{2}-E_{1 / 2}^{1}\right)$ to be $0.52,0.83$, and $0.31 \mathrm{~V}$ by utilizing glassy carbon as working electode with $0.1 \mathrm{M}$ tetrabutylammonium perchlorate in benzonitrile. These potentials are similar to those of $(S, S)$ - and $(R, R)-2$ with $E_{1 / 2}^{1}, E_{1 / 2}^{2}$, and $\Delta E$ of $0.52,0.80$, and $0.28 \mathrm{~V}$, respectively.

Preparations of single crystals for achiral charge transfer salt $\theta^{21}-[(S, S)-2]_{3}[(R, R)-2]_{3}\left(\mathrm{ClO}_{4}\right)_{2}$ and chiral charge transfer salt $\alpha^{\prime}-[(R, R)-2]_{2} \mathbf{C l O}_{4}\left(\mathrm{H}_{2} \mathrm{O}\right)$. The single brown plate crystals of $\theta^{21}-[(S, S)-2]_{3}[(R, R)-2]_{3}\left(\mathrm{ClO}_{4}\right)_{2}$ were grown by the oxidation of the racemic donor $2(7 \mathrm{mg})$ in the presence of tetrabutylammonium perchlorate $(44 \mathrm{mg})$ in dichloromethane $(24 \mathrm{~mL})$ at room temperature under a constant current of $0.5 \mu \mathrm{A}$ under a $\mathrm{N}_{2}$ atmosphere during the course of 6 days. The other chiral brown plate crystal of $\alpha^{\prime}-[(R, R)-2]_{2} \mathrm{ClO}_{4}\left(\mathrm{H}_{2} \mathrm{O}\right)$ was prepared electrochemically by utilizing $(R, R)-2(5 \mathrm{mg})$ and tetrabutylammonium perchlorate $(40 \mathrm{mg})$ in dichloromethane $(9 \mathrm{~mL})$ at $0.5 \mu \mathrm{A}$ for 5 days.

Crystal structures of achiral charge transfer salt $\theta^{21}-[(S, S)$ $2]_{3}[(R, R)-2]_{3}\left(\mathrm{ClO}_{4}\right)_{2}$ and chiral charge transfer salt $\boldsymbol{\alpha}^{\prime}-[(\boldsymbol{R}, \boldsymbol{R})-2]_{2} \mathrm{ClO}_{4}\left(\mathrm{H}_{2} \mathrm{O}\right)$. The crystal structure of $\theta^{21}-[(S, S)$ $2]_{3}[(R, R)-2]_{3}\left(\mathrm{ClO}_{4}\right)_{2}$ is depicted in Figure 2. The lattice parameters are listed in Table S1 in Supporting Information File 1. The crystallographically independent molecules are two $(S, S)-2$ (molecules $\mathrm{A}$ and $\mathrm{C}$ indicated by red in Figure $2 \mathrm{~b}$ ), one $(R, R)-\mathbf{2}$ (molecules $\mathrm{B}$ indicated by blue), and one $\mathrm{ClO}_{4}{ }^{-}$anion. The unit cell contains six donor molecules, consisting of three $(S, S)-2$ (molecules A, B', and $\mathrm{C}$ ) and three $(R, R)-2$ (molecules A', B and $C^{\prime}$ ), and two $\mathrm{ClO}_{4}{ }^{-}$anions. Molecules in a pair, $\mathrm{X}$ and $\mathrm{X}$ ' $(\mathrm{X}=\mathrm{A}, \mathrm{B}$, and $\mathrm{C})$ are related by an inversion center, so that the space group is centrosymmetric $P-1$ (No. 2). The donor arrangement is the $\theta^{21}$-type, where transvers inclination pattern is $++-++-\ldots(+$ and - represent upward and downward slopes, (a)

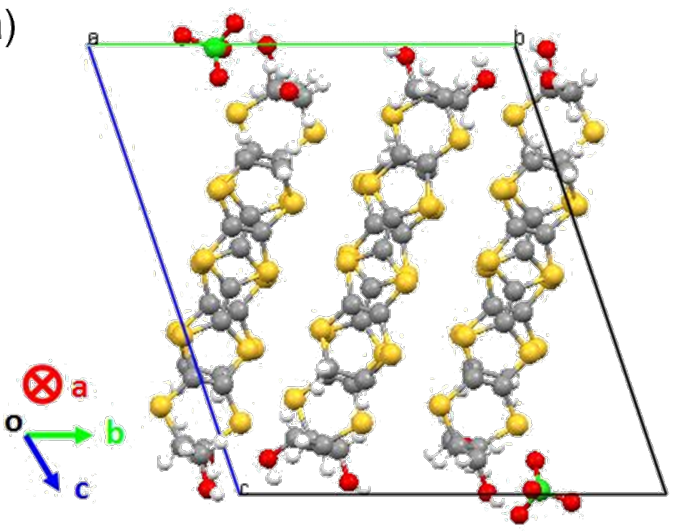

(b)

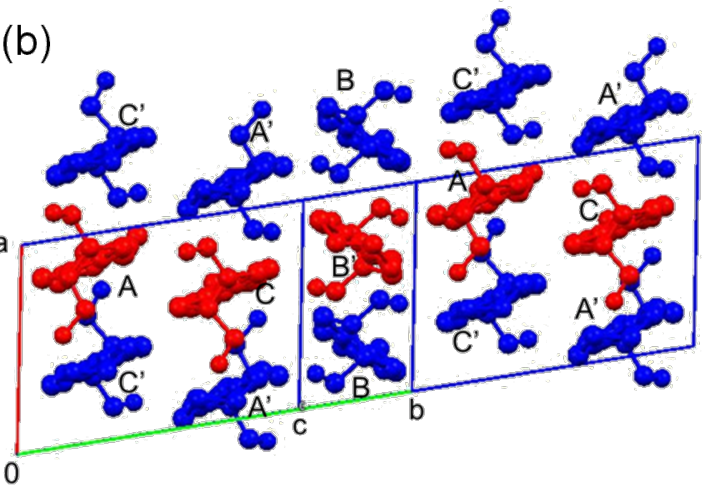

(c)

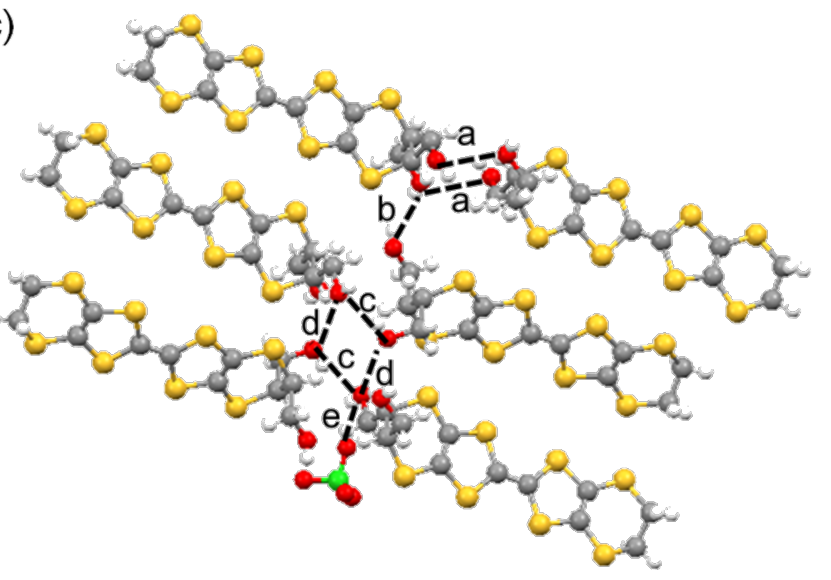

Figure 2: (a) Crystal structure, (b) $\theta^{21}$-type donor arrangement of molecules $A$ and $A^{\prime}[(S, S)$ and $(R, R)$-2 indicated by red and blue with charge of $+0.59(8)], \mathrm{B}$ and $\mathrm{B}^{\prime}[(R, R)$ and $(S, S)-2$, blue and red with $+0.23(7)]$, and $\mathrm{C}$ and $\mathrm{C}^{\prime}[(S, S)$ and $(R, R)-2$, red and blue with $+0.18(8)]$, and $(\mathrm{c}) \mathrm{O} \cdots \mathrm{O}$ hydrogen bond contacts of achital charge transfer salt $\theta^{21}-[(S, S)-2]_{3}[(R, R)-2]_{3}\left(\mathrm{ClO}_{4}\right)_{2} ; a=2.89(1), b=2.90(1), c=2.879(8), d=2.837(8)$, $e=2.94(1) \AA$. 
respectively), whereas the usual $\theta^{11}$-type has the $+-+-+-\ldots$ pattern [23]. In every $(+)$ and $(-)$-stacking column, the alternate $(R, R)-(S, S)-(R, R)-(S, S)$ - chiral donors indicated by blue-red-blue-red are stacked such as C'AC'A..., A'CA'C..., or BB'BB' ... in head-to-tail fashion (Figure 2b). Moreover, the molecules with the same chirality, $(R, R)$ or $(S, S)$, are arranged side-by-side along the $b$-axis. The charge of each molecule is estimated by bond analyses; as shown in Table S2 (Supporting Information File 1) [24], the charges of molecules A, B, and C are $+0.59(8),+0.23(7)$, and $+0.18(8)$, respectively. In the $(+)$ stacking column, the charge rich A $(+0.59(8))$ and charge poor $\mathrm{C}(+0.18(8))$ stack, whereas $\mathrm{B}$ with the medium charge $(+0.23(7))$ is arranged in the $(-)$-column, constructing the appropriate charge balance. The introduced hydroxymethyl groups are set to axial positions for donors $\mathrm{A}, \mathrm{B}$, and $\mathrm{C}$ (Figure $2 b$ ). Following the molecular design, many intermediate-strength intermolecular $\mathrm{O} \cdots \mathrm{O}$ hydrogen bonds $(<2.6-3.0 \AA)$ between hydroxymethyl groups in the donors $(a=2.89(1)$, $b=2.90(1), c=2.879(8)$, and $d=2.837(8) \AA$ in Figure 2c), and between a hydroxymethyl group in the donor and a $\mathrm{ClO}_{4}{ }^{-}$anion (e = 2.94(1) $\AA$ ) were observed, presumably helping the crystallinity of the complex based upon chiral molecules.

The crystal structure of the chiral salt $\alpha^{\prime}-[(R, R)-2]_{2} \mathrm{ClO}_{4}\left(\mathrm{H}_{2} \mathrm{O}\right)$ is shown in Figure 3. The crystallographically independent molecules are two $(R, R)-\mathbf{2}$ donors, one $\mathrm{ClO}_{4}{ }^{-}$anion, and one

(a)

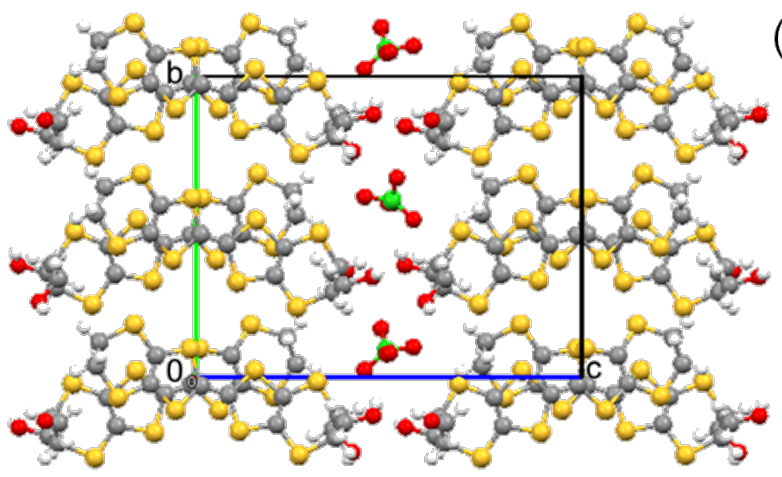

(c)

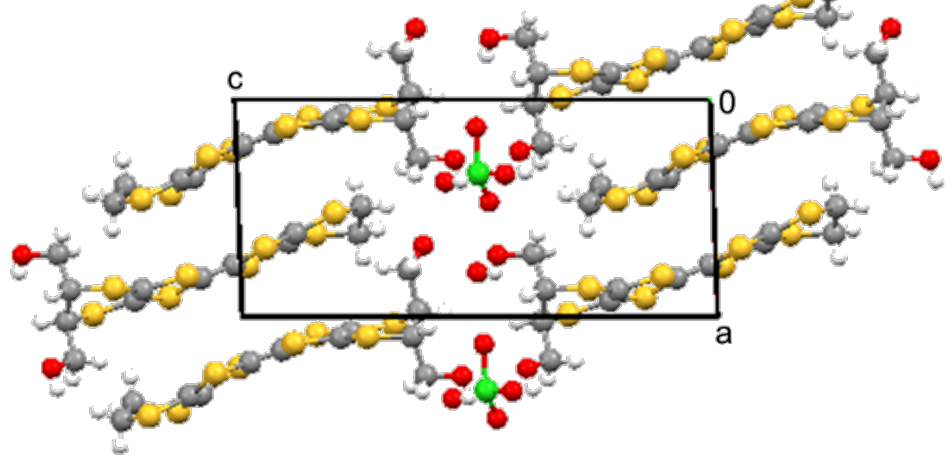

(d)

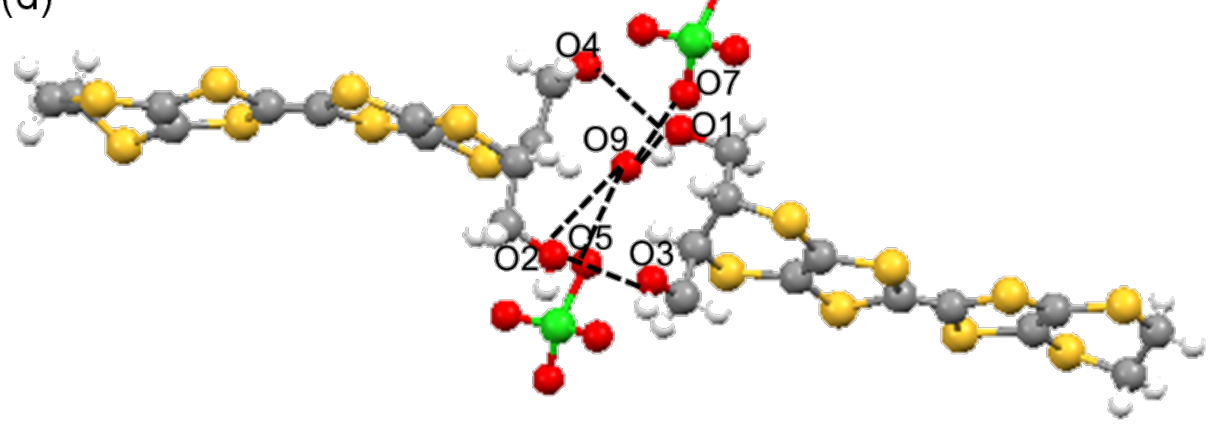

Figure 3: Crystal structure (a) viewed along the a-axis, (b) donor arrangement, (c) viewed along the $b$-axis, and (d) intermolecular hydrogen bond contacts for chiral charge transfer salt $\alpha^{\prime}-[(R, R)-2]_{2} \mathrm{ClO}_{4}\left(\mathrm{H}_{2} \mathrm{O}\right)$. The calculated hydrogen bonds are as follows; $r(\mathrm{O} 1 \cdots \mathrm{O} 4)=2.67(3), r(\mathrm{O} 1 \cdots \mathrm{O} 9)=$ $3.00(3), r(\mathrm{O} 2 \cdots \mathrm{O} 3)=2.67(2), r(\mathrm{O} 2 \cdots \mathrm{O} 9)=2.85(3), r(\mathrm{O} 5 \cdots \mathrm{O} 9)=2.62(6)$, and $r(\mathrm{O} 7 \cdots \mathrm{O} 9)=2.90(6) \AA$. 
$\mathrm{H}_{2} \mathrm{O}$ molecule as an included solvent. There are four donors, two anions, and two $\mathrm{H}_{2} \mathrm{O}$ solvents in the unit cell. The enantiopure $(R, R)-2$ donors stack in a head-to-tail manner and twisted with respect to each other along the $a$-axis, namely the $\alpha^{\prime}$-type donor arrangement [25].

The hydroxymethyl groups project from the molecular BEDTTTF plane in axial positions (Figure 3c). According to the molecular design, the intermolecular moderate hydrogen bonds between the oxygen atoms in hydroxymethyl groups of $(R, R)-2$ donors are observed such as $r(\mathrm{O} 1 \cdots \mathrm{O} 4)=2.67(3)$ and $r(\mathrm{O} 2 \cdots \mathrm{O} 3)=2.67(2) \AA$ (Figure $3 \mathrm{~d})$. The other hydrogen bonds are found between the oxygen atoms of either included $\mathrm{H}_{2} \mathrm{O}$ solvent and hydroxymethyl groups such as $r(\mathrm{O} 1 \cdots \mathrm{O} 9)=3.00(3)$ and $r(\mathrm{O} 2 \cdots \mathrm{O} 9)=2.85(3) \AA$, or of a solvent $\mathrm{H}_{2} \mathrm{O}$ and an anion $\mathrm{ClO}_{4}{ }^{-}$such as $r(\mathrm{O} 5 \cdots \mathrm{O} 9)=2.62(6)$ and $r(\mathrm{O} 7 \cdots \mathrm{O} 9)=2.90(6) \AA$ These hydrogen bonds contribute to forming this chiral crystal.

This chiral crystal $\alpha^{\prime}-[(R, R)-\mathbf{2}]_{2} \mathrm{ClO}_{4}\left(\mathrm{H}_{2} \mathrm{O}\right)$ is not isostructural to the other enantiopure crystal $\alpha^{\prime}-[(S, S)-2]_{2} \mathrm{ClO}_{4}$, previously reported (Table S1, Supporting Information File 1) [22]. The crystallographically independent donors are two for $\alpha^{\prime}-[(R, R)$ $5]_{2} \mathrm{ClO}_{4}\left(\mathrm{H}_{2} \mathrm{O}\right)$ in the space group $P 2_{1}$ (No. 4), but one for $\alpha^{\prime}-[(S, S)-5]_{2} \mathrm{ClO}_{4}$ in $P 2$ (No. 3). Although this $\alpha^{\prime}-[(R, R)-$ $2]_{2} \mathrm{ClO}_{4}\left(\mathrm{H}_{2} \mathrm{O}\right)$ crystal includes a $\mathrm{H}_{2} \mathrm{O}$ solvent molecule and $\alpha^{\prime}-[(S, S)-2]_{2} \mathrm{ClO}_{4}$ does not in the same preparation conditions, both salts have the similar $\alpha$-type donor arrangements.

Electrical resistivities for the achiral charge transfer salt $\theta^{21}-[(S, S)-2]_{3}[(R, R)-2]_{3}\left(C_{10}\right)_{2}$ and the chiral salt $\alpha^{\prime}-[(R, R)-$ $2]_{2} \mathrm{ClO}_{4}\left(\mathrm{H}_{2} \mathrm{O}\right)$. Temperature dependences of electrical resistivites for the achiral charge transfer salt $\theta^{21}-[(S, S)-2]_{3}[(R, R)$ $2]_{3}\left(\mathrm{ClO}_{4}\right)_{2}$ and the chiral salt $\alpha^{\prime}-[(R, R)-2]_{2} \mathrm{ClO}_{4}\left(\mathrm{H}_{2} \mathrm{O}\right)$ are shown in Figure 4. The resistivities at room temperature are very similar, 1.2 and $0.6 \mathrm{ohm} \mathrm{cm}$ for $\theta^{21}-[(S, S)-2]_{3}[(R, R)-$
$2]_{3}\left(\mathrm{ClO}_{4}\right)_{2}$ and $\alpha^{\prime}-[(R, R)-2]_{2} \mathrm{ClO}_{4}\left(\mathrm{H}_{2} \mathrm{O}\right)$, respectively. Both salts show semiconducting behaviour and the activation energy of $\theta^{21}-[(S, S)-2]_{3}[(R, R)-2]_{3}\left(\mathrm{ClO}_{4}\right)_{2}$ is $E_{\mathrm{a}}=86 \mathrm{meV}$ which is lower than that of $\alpha^{\prime}-[(R, R)-2]_{2} \mathrm{ClO}_{4}\left(\mathrm{H}_{2} \mathrm{O}\right)$ which has $E_{\mathrm{a}}=140 \mathrm{meV}$.

\section{Conclusion}

In summary, we have synthesized redox-active racemic and enantiopure donors of BEDT-TTF derivatives containing one or two hydroxymethyl groups, the novel racemic trans-vic(hydroxymethyl)(methyl)-BEDT-TTF 1 and enantiopure vicbis(hydroxymethyl)-BEDT-TTF 2. By successful molecular design to introduce intermolecular hydrogen bonds, the achiral charge transfer salt $\theta^{21}-[(S, S)-2]_{3}[(R, R)-2]_{3}\left(\mathrm{ClO}_{4}\right)_{2}$ and the chiral salt $\alpha^{\prime}-[(R, R)-2] \mathrm{ClO}_{4}\left(\mathrm{H}_{2} \mathrm{O}\right)$ could be obtained, and their crystal structure analyses and measurements of electrical resistivities were performed. In the racemic complex $\theta^{21}$ - $[(S, S)$ $2]_{3}[(R, R)-2]_{3}\left(\mathrm{ClO}_{4}\right)_{2},(S, S)-2$ and $(R, R)-2$ donors stack alternately along the $a$-axis and the same chiral $(S, S)$-2 (or $(R, R)-2$ ) donors are arranged in the side-by-side interaction to construct the stripe chirality order. The latter chiral salt $\alpha^{\prime}-[(R, R)$ 2] $\mathrm{ClO}_{4}\left(\mathrm{H}_{2} \mathrm{O}\right)$ is not isostructural with $\alpha^{\prime}-[(S, S)-2] \mathrm{ClO}_{4}$ without $\mathrm{H}_{2} \mathrm{O}$, but has a similar $\alpha$-type donor arrangement. According to the molecular design, both crystals have many moderatestrength hydrogen bonds of 2.6-3.0 $\AA$ between donor molecules, $\mathrm{ClO}_{4}{ }^{-}$anions, and $\mathrm{H}_{2} \mathrm{O}$, which contribute to crystallinity based upon chiral molecules and allow the investigation of physical properties. The promising strategy of chiral crystal growth will lead to the development of the versatile functionalities of molecular chiral crystals.

\section{Experimental \\ General information}

The parent racemic-2 (Figure 1) was synthesized according to the literature [22]. ${ }^{1} \mathrm{H}$ NMR $(300 \mathrm{MHz})$ and ${ }^{13} \mathrm{C}$ NMR (75 MHz) spectra were measured with a JEOL JNM-AL300
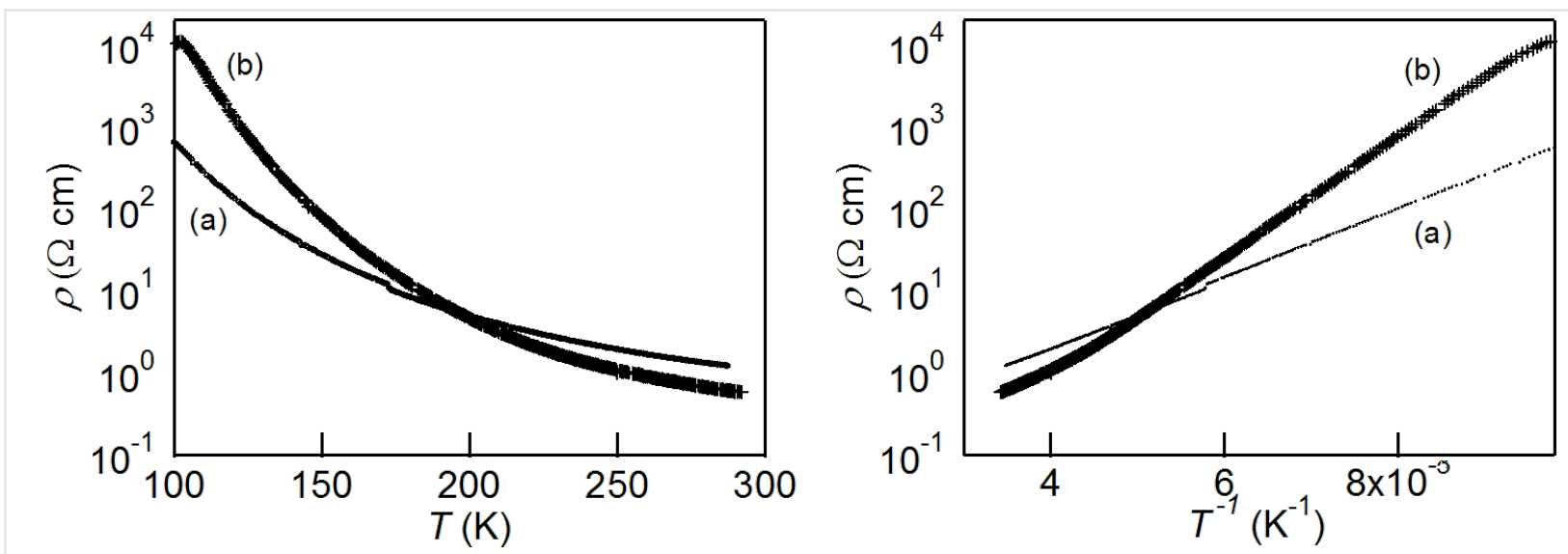

Figure 4: Temperature dependences of electrical resistivities for (a) achiral charge transfer salt $\theta^{21}-[(S, S)-2]_{3}[(R, R)-2]_{3}\left(C l O_{4}\right)_{2}$ and $(b)$ chiral salt $\alpha^{\prime}-[(R, R)-2]_{2} \mathrm{ClO}_{4}\left(\mathrm{H}_{2} \mathrm{O}\right)$. 
spectrometer with $\mathrm{CDCl}_{3}$ as solvent using $\mathrm{Me}_{4} \mathrm{Si}$ or residual solvent as an internal standard. Cyclic voltammetry (CV) measurements were performed on an ALS 610DB electrochemical analyzer in benzonitrile containing $0.1 \mathrm{M}$ tetrabutylammonium perchlorate (working electrode: $\mathrm{Pt}$, counter electrode: Pt wire, reference electrode: saturated calomel electrode (SCE)) [22]. EI-mass spectra were obtained with a JEOL JMS-AX500 spectrometer. X-ray crystallographic measurements were made on a Rigaku AFC-7R diffractometer (Mo K $\alpha, \lambda=0.71073 \AA$ ). The crystal structures were solved by direct methods and refined with full-matrix least-squares technique using Crystal Structure (ver. 4.0.1, Rigaku Co. and Rigaku Americas Co.). Anisotropic thermal parameters were applied to all non-hydrogen atoms. The hydrogen atoms were generated geometrically $(\mathrm{C}-\mathrm{H}=0.960 \AA)$. The direct current electrical conductivity measurement was made by the conventional four-probe method using carbon paste and gold wires.

\section{Synthesis of racemic-1}

trans-5-(Hydroxymethyl)-6-methyl-5,6-dihydro[1,3]dithiolo[4,5-b][1,4]dithiine-2-thione (9). A solution of trithione 7 (1 g, $5.1 \mathrm{mmol}, 1$ equiv) and alkene $8(0.52 \mathrm{~mL}, 6.12 \mathrm{mmol}$, 1.2 equiv, trans-form $96 \%)$ in toluene $(50 \mathrm{~mL})$ was refluxed overnight. The toluene was removed under reduced pressure and the crude material purified by column chromatography (silica gel, 2:1 hexane:ethyl acetate) to afford the trans-thione 9 as a brown powder (with small amounts of the cis derivative). This material was recrystallized from dichloromethane/hexane to give the trans-thione 9 as a brown powder $(0.77 \mathrm{~g}, 56 \%)$. ${ }^{1} \mathrm{H} \mathrm{NMR}\left(300 \mathrm{MHz}, \mathrm{CDCl}_{3}\right) \delta 1.55(\mathrm{~d}, J=6.6 \mathrm{~Hz}, 3 \mathrm{H}), 1.98$ (dd, $J=5.1,6.6 \mathrm{~Hz}, 1 \mathrm{H}), 3.36(\mathrm{ddd}, J=3.9,6.3,7.5 \mathrm{~Hz}, 1 \mathrm{H})$, $3.64(\mathrm{dq}, J=3.9,6.9 \mathrm{~Hz}, 1 \mathrm{H}), 3.86(\mathrm{~m}, 2 \mathrm{H}) ;{ }^{13} \mathrm{C} \mathrm{NMR}$ $\left(75 \mathrm{MHz}, \mathrm{CDCl}_{3}\right) \delta 21.90,37.07,49.95,64.89,120.20,120.46$, 207.57.

trans-5-(Acetoxymethyl)-6-methyl-5,6-dihydro[1,3] dithiolo[4,5-b][1,4]dithiine-2-thione (10). To a solution of thione 9 (482 mg, $1.80 \mathrm{mmol}, 1$ equiv) in pyridine $(5 \mathrm{~mL})$ was added acetic anhydride (202 mg, $1.98 \mathrm{mmol}, 1.1$ equiv). The reaction mixture was stirred overnight under argon at room temperature. Dichloromethane $(50 \mathrm{~mL})$ was added, the organic phase was washed with $1 \mathrm{M} \mathrm{HCl}(2 \times 50 \mathrm{~mL})$ and water $(50 \mathrm{~mL})$, dried over $\mathrm{MgSO}_{4}$, filtered and reduced in vacuo to give the required product 10 as a brown oil (560 mg, 100\%). The material was used in the next step without further purification. ${ }^{1} \mathrm{H}$ NMR $\left(300 \mathrm{MHz}, \mathrm{CDCl}_{3}\right) \delta 1.50(\mathrm{~d}, J=6.9 \mathrm{~Hz}, 3 \mathrm{H}), 2.03(\mathrm{~s}, 3 \mathrm{H}), 3.42$ (ddd, $J=3.9,6.6,7.8 \mathrm{~Hz}, 1 \mathrm{H}), 3.50$ (dq, $J=3.9,6.9 \mathrm{~Hz}, 1 \mathrm{H})$, $4.22(\mathrm{dd}, J=7.5,11.7 \mathrm{~Hz}, 1 \mathrm{H}), 4.27$ (dd, $J=6.0,11.7 \mathrm{~Hz}, 1 \mathrm{H})$; ${ }^{13} \mathrm{C}$ NMR $\left(75 \mathrm{MHz}, \mathrm{CDCl}_{3}\right) \delta 20.69,21.82,37.13,45.86$, $65.66,119.44,119.82,170.33,207.20$.
trans-5-(Acetoxymethyl)-6-methyl-5,6-dihydro[1,3]dithiolo[4,5-b][1,4]dithiine-2-one (11). To a solution of thione 10 (560 mg, $1.81 \mathrm{mmol}, 1$ equiv) in chloroform $(30 \mathrm{~mL})$ was added mercuric acetate ( $843 \mathrm{mg}, 2.71 \mathrm{mmol}, 1.5$ equiv) and acetic acid $(5 \mathrm{~mL})$. The reaction mixture was stirred for 3 hours at room temperature. The solution was filtered, washed with sat. $\mathrm{NaHCO}_{3}(2 \times 50 \mathrm{~mL})$ and water $(50 \mathrm{~mL})$, dried over $\mathrm{MgSO}_{4}$, filtered and reduced in vacuo to give the oxo compound $\mathbf{1 1}$ (480 mg, 90\%) as a yellow solid. ${ }^{1} \mathrm{H}$ NMR (300 $\left.\mathrm{MHz}, \mathrm{CDCl}_{3}\right)$ $\delta 1.53(\mathrm{~d}, J=6.6 \mathrm{~Hz}, 3 \mathrm{H}), 2.03$ (s, 3H), 3.40 (ddd, $J=3.9,6.3$, $7.2 \mathrm{~Hz}, 1 \mathrm{H}), 3.46(\mathrm{dq}, J=3.9,6.6 \mathrm{~Hz}, 1 \mathrm{H}), 4.28(\mathrm{~m}, 2 \mathrm{H})$; ${ }^{13} \mathrm{C}$ NMR $\left(75 \mathrm{MHz}, \mathrm{CDCl}_{3}\right) \delta 20.73,21.80,38.50,47.59$, $65.82,110.40,110.61,116.36,170.43$.

trans-vic-Acetoxymethyl-methyl-BEDT-TTF (13). A solution of thione 12 (439 mg, $1.96 \mathrm{mmol}, 1.2$ equiv) and the oxocompound 11 (480 mg, $1.63 \mathrm{mmol}, 1$ equiv) in triethyl phosphite $(10 \mathrm{~mL})$ was stirred overnight at $90{ }^{\circ} \mathrm{C}$. After cooling, hexane was added and the precipitate collected by vacuum filtration and purified by column chromatography (silica gel, 4:1 hexane/ethyl acetate) to afford the cross-coupled product $\mathbf{1 3}$ as a red-orange solid (280 mg, 37\%). ${ }^{1} \mathrm{H}$ NMR (300 MHz, $\left.\mathrm{CDCl}_{3}\right) \delta 1.44(\mathrm{~d}, J=6.6 \mathrm{~Hz}, 3 \mathrm{H}), 2.05(\mathrm{~s}, 3 \mathrm{H}), 3.26(\mathrm{~s}, 4 \mathrm{H})$, 3.38 (ddd, $J=3.9,6.3,7.5 \mathrm{~Hz}, 1 \mathrm{H}), 3.43(\mathrm{dq}, J=3.9,6.6 \mathrm{~Hz}$, $1 \mathrm{H}), 4.18(\mathrm{dd}, J=7.5,11.4 \mathrm{~Hz}, 1 \mathrm{H}), 4.24(\mathrm{dd}, J=6.3,11.4 \mathrm{~Hz}$, $1 \mathrm{H}) ;{ }^{13} \mathrm{C} \mathrm{NMR}\left(75 \mathrm{MHz}, \mathrm{CDCl}_{3}\right) \delta 20.75,21.58,30.06,37.80$, $46.56,65.80,110.54,110.77,110.97,111.86,113.69,170.35$.

trans-vic-Hydroxymethyl-methyl-BEDT-TTF (1). A solution of the acetyl protected BEDT-TTF $13(280 \mathrm{mg}, 0.596 \mathrm{mmol}$, 1 equiv) and $\mathrm{K}_{2} \mathrm{CO}_{3}$ (95 mg, $0.894 \mathrm{mmol}, 1.5$ equiv) in $\mathrm{MeOH} /$ $\mathrm{H}_{2} \mathrm{O} / \mathrm{THF}(5 \mathrm{~mL} / 5 \mathrm{~mL} / 5 \mathrm{~mL})$ was stirred overnight at room temperature under an argon atmosphere. Water $(50 \mathrm{~mL})$ and dichloromethane $(100 \mathrm{~mL})$ were added, the organic layer separated and washed with water $(2 \times 50 \mathrm{~mL})$. The organic layer was dried over $\mathrm{MgSO}_{4}$, filtered and evaporated to give the crude product that was purified by column chromatography (silica gel, ethyl acetate) to afford the trans-racemic BEDT-TTF derivative 1 as an orange powder $(210 \mathrm{mg}, 81 \%)$. ${ }^{1} \mathrm{H}$ NMR $\left(300 \mathrm{MHz}, \mathrm{CDCl}_{3}\right) \delta 1.43(\mathrm{~d}, J=6.6 \mathrm{~Hz}, 3 \mathrm{H}), 1.85(\mathrm{br} \mathrm{s}, 1 \mathrm{H})$, $3.22(\mathrm{~s}, 4 \mathrm{H}), 3.24(\mathrm{~m}, 1 \mathrm{H}), 3.46(\mathrm{dq}, J=3.6,6.6 \mathrm{~Hz}, 1 \mathrm{H}), 3.71$ $(\mathrm{m}, 2 \mathrm{H}) ;{ }^{13} \mathrm{C}$ NMR (75 MHz, DMSO- $\left.d_{6}\right) \delta 21.29,29.58,37.39$, 50.37, 63.98, 110.03, 110.11, 110.44, 111.62, 112.93, MS m/z: $[\mathrm{M}-\mathrm{OH}]^{+}$calcd for $\mathrm{C}_{12} \mathrm{H}_{11} \mathrm{~S}_{8}, 411$; found, 410.8627 .

\section{Synthesis of $(S, S)-2$}

$(S, S)$-trans-5,6-Bis(acetyloxymethyl)-5,6-dihydro-1,3dithiolo[4,5-b]-1,4-dithiin-2-thione $((S, S)-15)$. A solution of the dihydroxythione $(S, S)-14$ (25 $\mathrm{mg}, 0.088 \mathrm{mmol}, 1$ equiv) in pyridine $(1 \mathrm{~mL})$ and acetic anhydride $(0.02 \mathrm{~mL}, 1.96 \mathrm{mmol}$, 20 equiv) was stirred at room temperature overnight under an 
argon atmosphere. The reaction mixture was taken up in dichloromethane and washed briefly with $1 \mathrm{M} \mathrm{HCl}(2 \times 50 \mathrm{~mL})$ and water $(50 \mathrm{~mL})$. The organic layer was dried over $\mathrm{MgSO}_{4}$, filtered and the volatiles removed in vacuo to give the crude enantiopure diacetoxythione $(S, S)-\mathbf{1 5}$ (32 $\mathrm{mg}$, quantitative). The isolated product was used in the next step without further purification. ${ }^{1} \mathrm{H}$ NMR $\left(300 \mathrm{MHz}, \mathrm{CDCl}_{3}\right) \delta 2.12(\mathrm{~s}, 6 \mathrm{H}), 3.79(\mathrm{~m}$, $2 \mathrm{H}), 4.32(\mathrm{dd}, J=8.1,11.4 \mathrm{~Hz}, 2 \mathrm{H}), 4.42(\mathrm{dd}, J=6.0,11.4 \mathrm{~Hz}$, $2 \mathrm{H}) ;{ }^{13} \mathrm{C} \mathrm{NMR}\left(75 \mathrm{MHz}, \mathrm{CDCl}_{3}\right) \delta 20.69,40.06,64.71,118.79$, 170.28, 206.49 .

(S,S)-trans-5,6-Bis(acetoxymethyl)-5,6-dihydro-1,3dithiolo[4,5-b]-1,4-dithiin-2-one $((S, S)-16)$. To a solution of thione $(S, S)-15$ (32 mg, $0.087 \mathrm{mmol}, 1$ equiv) in chloroform $(10 \mathrm{~mL})$ was added mercuric acetate $(35 \mathrm{mg}, 0.11 \mathrm{mmol}$, 1.3 equiv) and acetic acid $(0.5 \mathrm{~mL})$. The reaction mixture was stirred for 3 hours, after which it was filtered, washed with (sat.) $\mathrm{NaHCO}_{3}(3 \times 50 \mathrm{~mL})$ and water $(50 \mathrm{~mL})$. The organic layer was dried over $\mathrm{MgSO}_{4}$, filtered and the solvent removed under reduced pressure to afford the oxo compound $(S, S)-16(28 \mathrm{mg}$ (93\%). ${ }^{1} \mathrm{H}$ NMR $\left(300 \mathrm{MHz}, \mathrm{CDCl}_{3}\right) \delta 2.12(\mathrm{~s}, 6 \mathrm{H}), 3.76(\mathrm{~m}$, $2 \mathrm{H}), 4.38(\mathrm{dd}, J=7.5,11.4 \mathrm{~Hz}, 2 \mathrm{H}), 4.45(\mathrm{dd}, J=5.7,11.4 \mathrm{~Hz}$, $2 \mathrm{H}) ;{ }^{13} \mathrm{C} \mathrm{NMR}\left(75 \mathrm{MHz}, \mathrm{CDCl}_{3}\right) \delta 20.69,41.40,64.84,109.72$, $170.35,187.57$.

(S,S)-trans-vic-Bis(acetyloxymethyl)-BEDT-TTF ((S,S)-17). A solution of thione 12 (64 mg, $0.16 \mathrm{mmol}, 2$ equiv) and oxo compound $(S, S)-16$ (50 mg, $0.14 \mathrm{mmol}, 1$ equiv) in triethyl phosphite $(2 \mathrm{~mL})$ was stirred at $90{ }^{\circ} \mathrm{C}$ for 5 hours. After cooling hexane was added, the precipitate collected and purified by column chromatography (silica gel, hexane/ethyl actetate) to afford the enantiopure cross coupled product $(S, S)-17$ (34 mg, 47\%). ${ }^{1} \mathrm{H}$ NMR (300 MHz, $\left.\mathrm{CDCl}_{3}\right) \delta 2.09$ (s, 6H), 3.29 (s, 4H), $3.69(\mathrm{~m}, 2 \mathrm{H}), 4.25$ (dd, $J=7.8,11.4 \mathrm{~Hz}, 2 \mathrm{H}), 4.34$ (dd, $J=6.0$, $11.4 \mathrm{~Hz}, 2 \mathrm{H}) ;{ }^{13} \mathrm{C} \mathrm{NMR}\left(75 \mathrm{MHz}, \mathrm{CDCl}_{3}\right) \delta 20.73,30.17$, $40.88,64.93,110.43,113.92,170.35$.

(S,S)-trans-vic-Bis(hydroxymethyl)-BEDT-TTF ((S,S)-2). $\mathrm{K}_{2} \mathrm{CO}_{3}$ (27 mg, $0.193 \mathrm{mmol}, 3$ equiv) was added to a solution of the acetyl protected BEDT-TTF $((S, S)-\mathbf{1 7}, 34 \mathrm{mg}$, $0.064 \mathrm{mmol})$ in $\mathrm{MeOH} / \mathrm{THF} / \mathrm{H}_{2} \mathrm{O}(1 \mathrm{~mL} / 1 \mathrm{~mL} / 1 \mathrm{~mL})$. The reaction mixture was stirred for 3 hours under an argon atmosphere, after which no starting material remained (TLC control). Dichloromethane $(100 \mathrm{~mL})$ was added and the organic layer washed with water $(2 \times 20 \mathrm{~mL})$. The organic layer was dried over $\mathrm{MgSO}_{4}$, filtered and the solvent was removed under reduced pressure. The crude material was purified by column chromatography (silica gel, 1:1 hexane/ethyl acetate) to afford the desired product $(S, S)-2(23 \mathrm{mg}, 80 \%)$ as a red-pink solid. ${ }^{1} \mathrm{H}$ NMR (300 MHz, DMSO- $\left.d_{6}\right) \delta 3.34(\mathrm{~s}, 4 \mathrm{H})$, $3.58(\mathrm{~m}, 4 \mathrm{H}), 3.71(\mathrm{~m}, 2 \mathrm{H}), 4.44(\mathrm{~m}, 2 \mathrm{H}) ;{ }^{13} \mathrm{C} \mathrm{NMR}(75 \mathrm{MHz}$,
DMSO- $\left.d_{6}\right) \delta 30.83,45.82,67.40,111.24,111.38,111.97$, 114.44 .

\section{Supporting Information}

\section{Supporting Information File 1}

CD spectra of $(S, S)$-2 and $(R, R)$-2, crystal data for

$\theta^{21}-[(S, S)-2]_{3}[(R, R)-2]_{3}\left(\mathrm{ClO}_{4}\right)_{2}, \alpha^{\prime}-[(R, R)-\mathbf{2}]_{2} \mathrm{ClO}_{4}\left(\mathrm{H}_{2} \mathrm{O}\right)$,

and $\alpha^{\prime}-[(S, S)-2]_{2} \mathrm{ClO}_{4}$ (Table $\left.\mathrm{S} 1\right)$, charge estimation of

$\theta^{21}-[(S, S)-2]_{3}[(R, R)-2]_{3}\left(\mathrm{ClO}_{4}\right)_{2}$ (Table S2, Figure S2), and

NMR data (Figures S3-1-S3-18).

[http://www.beilstein-journals.org/bjoc/content/

supplementary/1860-5397-11-172-S1.pdf]

\section{Acknowledgements}

This work was partially supported by Grants in-Aid for Scientific Research (Nos. 26810044, 24340074, and 26610096) from Japan Society for the Promotion Science (JSPS), Japan, the Yazaki Memorial Foundation for Science and Technology and the Mitsubishi Foundation.

\section{References}

1. Inoue, K.; Ohkoshi, S.; Imai, H. Chiral Molecule-Based Magnets. In Magnetism: Molecules to Materials V; Miller, J.; Drillon, M., Eds.; Wiley-VCH: Weinheim, 2005; pp 41-70.

2. Rikken, G. L. J. A.; Raupach, E. Nature 1997, 390, 493-494. doi: $10.1038 / 37323$

3. Rikken, G. L. J. A.; Raupach, E. Phys. Rev. E 1998, 58, 5081-5084. doi:10.1103/PhysRevE.58.5081

4. Rikken, G. L. J. A.; Fölling, J.; Wyder, P. Phys. Rev. Lett. 2001, 87, 236602. doi:10.1103/PhysRevLett.87.236602

5. Krstić, V.; Roth, S.; Burghard, M.; Kern, K.; Rikken, G. L. J. A. J. Chem. Phys. 2002, 117, 11315-11319. doi:10.1063/1.1523895

6. Krstić, V.; Rikken, G. L. J. A. Chem. Phys. Lett. 2002, 364, 51-56. doi:10.1016/S0009-2614(02)01243-5

7. Réthoré, C.; Avarvari, N.; Canadell, E.; Auban-Senzier, P.; Fourmigué, M. J. Am. Chem. Soc. 2005, 127, 5748-5749. doi:10.1021/ja0503884

8. Madalan, A. M.; Réthoré, C.; Fourmigué, M.; Canadell, E.; Lopes, E. B.; Almeida, M.; Auban-Senzier, P.; Avarvari, N. Chem. - Eur. J. 2010, 16, 528-537. doi:10.1002/chem.200901980

9. Pop, F.; Auban-Senzier, P.; Frackowiak, A.; Ptaszyński, K.; Olejniczak, I.; Wallis, J. D.; Canadell, E.; Avarvari, N. J. Am. Chem. Soc. 2013, 135, 17176-17186. doi:10.1021/ja408350r

10. Pop, F.; Auban-Senzier, P.; Canadell, E.; Rikken, G. L. J. A.; Avarvari, N. Nat. Commun. 2014, 5, 3757. doi:10.1038/ncomms4757

11. Wallis, J. D.; Karrer, A.; Dunitz, J. D. Helv. Chim. Acta 1986, 69, 69-70. doi:10.1002/hlca.19860690110

12. Karrer, A.; Wallis, J. D.; Dunitz, J. D.; Hilti, B.; Mayer, C. W.; Bürkle, M.; Pfeiffer, J. Helv. Chim. Acta 1987, 70, 942-953. doi:10.1002/hlca.19870700405

13. Wallis, J. D.; Dunitz, J. D. Acta Crystallogr., Sect. C: Cryst. Struct. Commun. 1988, 44, 1037-1039. doi:10.1107/S0108270188001593 
14. Matsumiya, S.; Izuoka, A.; Sugawara, T.; Taruishi, T.; Kawada, Y. Bull. Chem. Soc. Jpn. 1993, 66, 513-522. doi:10.1246/bcsj.66.513

15. Avarvari, N.; Wallis, J. D. J. Mater. Chem. 2009, 19, 4061-4076. doi:10.1039/B820598A

16. Zambounis, J. S.; Mayer, C. W.; Hauenstein, K.; Hilti, B.; Hofherr, W.; Pfeiffer, J.; Bürkle, M.; Rihs, G. Adv. Mater. 1992, 4, 33-35. doi:10.1002/adma.19920040106

17. Krivickas, S. J.; Ichikawa, A.; Takahashi, K.; Tajima, H.; Wallis, J. D.; Mori, H. Synth. Met. 2011, 161, 1563-1565. doi:10.1016/j.synthmet.2011.05.019

18. Konoike, T.; Iwashita, K.; Yoshino, H.; Murata, K.; Sasaki, T.; Papavassiliou, G. C. Phys. Rev. B 2002, 66, 245308. doi:10.1103/PhysRevB.66.245308

19. Zambounis, J. S.; Pfeiffer, J.; Papavassiliou, G. C.; Lagouvardos, D. J.; Terzis, A.; Raptopoulou, C. P.; Delhaès, P.; Ducasse, L.; Fortune, N. A.; Murata, K. Solid State Commun. 1995, 95, 211-215. doi:10.1016/0038-1098(95)00231-6

20. Leurquin, F.; Ozturk, T.; Pilkington, M.; Wallis, J. D. J. Chem. Soc., Perkin Trans. 1 1997, 3173-3177. doi:10.1039/A704364C

21. Brown, R. J.; Brooks, A. C.; Griffiths, J.; Vital, B.; Day, P.; Wallis, J. D. Org. Biomol. Chem. 2007, 5, 3172-3182. doi:10.1039/b709823e

22. Krivickas, S. J.; Hashimoto, C.; Takahashi, K.; Wallis, J. D.; Mori, H. Phys. Status Solidi C 2012, 9, 1146-1148. doi:10.1002/pssc.201100728

23. Mori, T.; Mori, H.; Tanaka, S. Bull. Chem. Soc. Jpn. 1999, 72, 179-197. doi:10.1246/bcsj.72.179

24. Guionneau, P.; Kepert, C. J.; Bravic, G.; Chasseau, D.; Truter, M. R.; Kurmoo, M.; Day, P. Synth. Met. 1997, 86, 1973-1974. doi:10.1016/S0379-6779(97)80983-6

25. Mori, T. Bull. Chem. Soc. Jpn. 1999, 72, 2011-2027. doi:10.1246/bcsj.72.2011

\section{License and Terms}

This is an Open Access article under the terms of the Creative Commons Attribution License (http://creativecommons.org/licenses/by/2.0), which permits unrestricted use, distribution, and reproduction in any medium, provided the original work is properly cited.

The license is subject to the Beilstein Journal of Organic Chemistry terms and conditions:

(http://www.beilstein-journals.org/bjoc)

The definitive version of this article is the electronic one which can be found at: doi:10.3762/bjoc.11.172 